\title{
Three new species of Croton (Euphorbiaceae s.s.) from the Brazilian Caatinga
}

\author{
Daniela S. Carneiro-Torres ${ }^{1,2}$, Inês Cordeiro ${ }^{3}$, Ana Maria Giulietti ${ }^{2}$, \\ Paul E. Berry ${ }^{4}$, AND Ricarda RiInA ${ }^{4,5}$
}

${ }^{1}$ Departamento de Ciências Biológicas, Universidade Estadual do Sudoeste da Bahia, R. José Moreira Sobrinho, s/n, Jequiezinho, Jequié, 45206-190, Bahia, Brazil; e-mail: anagiulietti@hotmail.com

${ }^{2}$ Universidade Estadual de Feira de Santana, Rodovia BR 116N, km 3, Feira de Santana, Bahia, 44031-460, Brazil; e-mail: dscarneiro@hotmail.com

${ }^{3}$ Instituto de Botânica, Seção de Curadoria do Herbário, Caixa Postal 3005, 001061-970, São

Paulo-SP, Brazil; e-mail: isandona@uol.com.br

${ }^{4}$ Department of Ecology and Evolutionary Biology, University of Michigan Herbarium, 3600

Varsity Drive, Ann Arbor, MI 48109-2287, USA; e-mail: peberry@umich.edu

${ }^{5}$ Real Jardín Botánico, CSIC, Plaza de Murillo 2, 28014 Madrid, Spain; e-mail: riina@umich.edu

\begin{abstract}
While conducting a floristic inventory of Croton from the Brazilian Caatinga, three new species were discovered. Croton arenosus, Croton glandulosobracteatus, and Croton harleyi are described and illustrated here. Based on morphological characters, Croton glandulosobracteatus is proposed to belong to section Barhamia, and C. arenosus and C. harleyi to section Geiseleria.
\end{abstract}

Key Words: Brazil, Caatinga, Croton, Euphorbiaceae.

The Brazilian term "Caatinga" refers both to a semi-arid vegetation type, as well as to a biogeographical region called the "região das Caatingas." This region is located entirely in Brazil between $3^{\circ}-17^{\circ} \mathrm{S}$ and $35^{\circ}$ $45^{\circ} \mathrm{W}$, where it covers ca. $850,000 \mathrm{~km}^{2}$, or about $10 \%$ of the country (Velloso et al., 2002; Queiroz et al., 2006). Caatinga vegetation extends across nine states of northeastern Brazil, including parts of Piauí, Ceará, Rio Grande do Norte, Paraíba, Pernambuco, Alagoas, Sergipe, Bahia, and Minas Gerais, and is characterized by a high annual evapotranspiration (1500-2000 mm/ year) and a low annual precipitation (300 $1000 \mathrm{~mm} /$ year), which is concentrated in three to five months of the year (Sampaio, 1995; Queiroz, 2006). According to Pennington et al. $(2000,2006)$ and Prado (2000), the Caatinga is one of the three major phytogeographic units integrating the broader category of Seasonal Tropical Dry Forests. Caatinga vegetation consists mainly of xeric shrublands and thorn forests, with many deciduous species (Queiroz, 2009). Other non-forest vegetation types can also be found within the Caatinga region, such as campos rupestres (rocky outcrops with herbaceous and shrubby vegetation above $900 \mathrm{~m}$ elevation) and cerrados (sclerophyllous vegetation growing in shallow and distrophic soils).

Caatinga vegetation was previously considered poor in plant species and endemism (Rizzini, 1979; Andrade Lima, 1982), and for that reason it was not considered valuable for conservation purposes. However, recent studies have shown that the Caatinga is considerably richer in species than previously thought, with 510 genera and 5344 species of vascular plants, of which 18 genera and 318 species are endemic (Giulietti et al., 2002; Prado, 2003). Giulietti et al. (2002) ranked Euphorbiaceae s. 1 . as the third largest family in Caatinga vegetation, with 73 species, after Fabaceae with 320 species (de Queiroz, 2009) and Convolvulaceae with 103 species. 
Croton L. is the second largest genus of the Euphorbiaceae, with about 1250 species of herbs, subshrubs, shrubs, and trees (Govaerts et al., 2000). Species in this genus can be easily recognized in the field by their stellate or lepidote indumentum (Webster et al., 1996), older leaves that often turn orange when senescent, glands commonly present at the base of the leaves, and raceme-like inflorescences of small unisexual flowers. The staminate flowers usually have numerous stamens and are distal on the inflorescence, and the pistillate flowers generally lack petals and are proximal on the inflorescence. Species of Croton are common elements of secondary vegetation in many tropical and subtropical regions, and they are especially important floristic elements of dry and semiarid regions like the Caatinga. Brazil is the country with the greatest diversity of Croton, with more than 300 species (Caruzo et al., 2008), followed by Madagascar and the Caribbean region each with ca. 150 species (Berry et al., 2005). Croton is the richest genus of the Caatinga ecoregion, with 68 species (Carneiro-Torres, 2009), followed by Mimosa with 61 species (Giulietti et al., 2002).

During the taxonomic revision of Croton in the Caatinga (Carneiro-Torres, 2009), three previously undescribed species were found. Based on morphological characters and preliminary DNA sequence data, we consider two of them, $C$. arenosus and C. harleyi, to belong to Croton section Geiseleria (Klotzsch) Baill. Based exclusively on morphological characters, we place the third species, C. glandulosobracteatus, in Croton section Barhamia (Klotzsch) Baill.

\section{Materials and methods}

This work is based on the analysis of populations of many species of Croton in the field by the first author throughout the Caatinga region and on the analysis of specimens from the following herbaria: ALCB, BR, CEPEC, EAC, ESA, F, G, HUEFS, HUESB, HRB, IPA, K, LE, M, MBM, MO, MOSS, NY, P, RB, SP, SPF, UFP, W, and WIS.

The descriptions of the new species were complemented by examination of the leaf indumentum using Scanning Electron Microscopy (SEM). The following specimens, deposited at HUEFS, were examined by SEM: E.B. Miranda et al. 613 (C. arenosus), E.B. Souza et al. 1035 (C. glandulosobracteatus), and A. Fernandes et al. s.n., HUEFS 106352 (C. harleyi). Samples of leaf fragments were photographed on a SEM LEO 1430VP at the Universidade Estadual de Feira de Santana. The terminology used to describe the trichomes follows Webster et al. (1996).

The species distribution map was created in Arcview GIS 3.2 (ESRI 1999) using the Caatinga Domain map of Velloso et al. (2002) as the base map. The geographic coordinates of localities were obtained from the specimen labels, or lacking that information, from the municipalities in the database of the Instituto Brasileiro de Geografia e Estatistica-IBGE (http://www.ibge.org.br).

\section{New species}

Croton arenosus Carn.-Torres \& Cordeiro, sp. nov. TYPE: Brazil. Bahia: Município de Canudos, Reserva Biológica Esquentada, $9^{\circ} 56^{\prime} 58^{\prime \prime} \mathrm{S} 38^{\circ} 58^{\prime} 48^{\prime \prime} \mathrm{W}, 440 \mathrm{~m}$ alt., 18 Feb 2004 (fl), E. B. Miranda, R. M. Harley, F. H. Silva \& B. M. Silva 613 (holotype: HUEFS), (Figs. 1B-D, 2A-J, 5A-D, 6).

Crotoni triangulari Müll. Arg. affinis sed foliis ellipticis-ovatis, ad margines eglandulosis, sepalis femineis inaequalilus, ovariis lepidotis, stylis bifidis differt.

Monoecious shrub to subshrub, erect, 0.7$1.5 \mathrm{~m}$ tall, branches silvery-green, with fasciculate and stellate-lepidote trichomes with a porrect central radius, latex clear. Leaves alternate, simple, membranaceous to papyraceous, penninerved, blade elliptic to ovate, $0.9-2.5 \times 0.8-2.0 \mathrm{~cm}$, apex acute, base rounded, symmetric, with 2 sessile, circular glands at the base of the blade on the lower surface, margin crenate to serrulate, adaxial surface scabrous, with fasciculate trichomes, abaxial surface tomentose, cinereous, trichomes stellate-lepidote with a porrect central radius; petiole $2-5 \mathrm{~mm}$ long, scabrous; stipules entire, lanceolate, $1-1.5 \mathrm{~mm}$ long, deciduous. Inflorescences terminal, bisexual, 2-4.5 cm long, scabrous, trichomes stellate- 

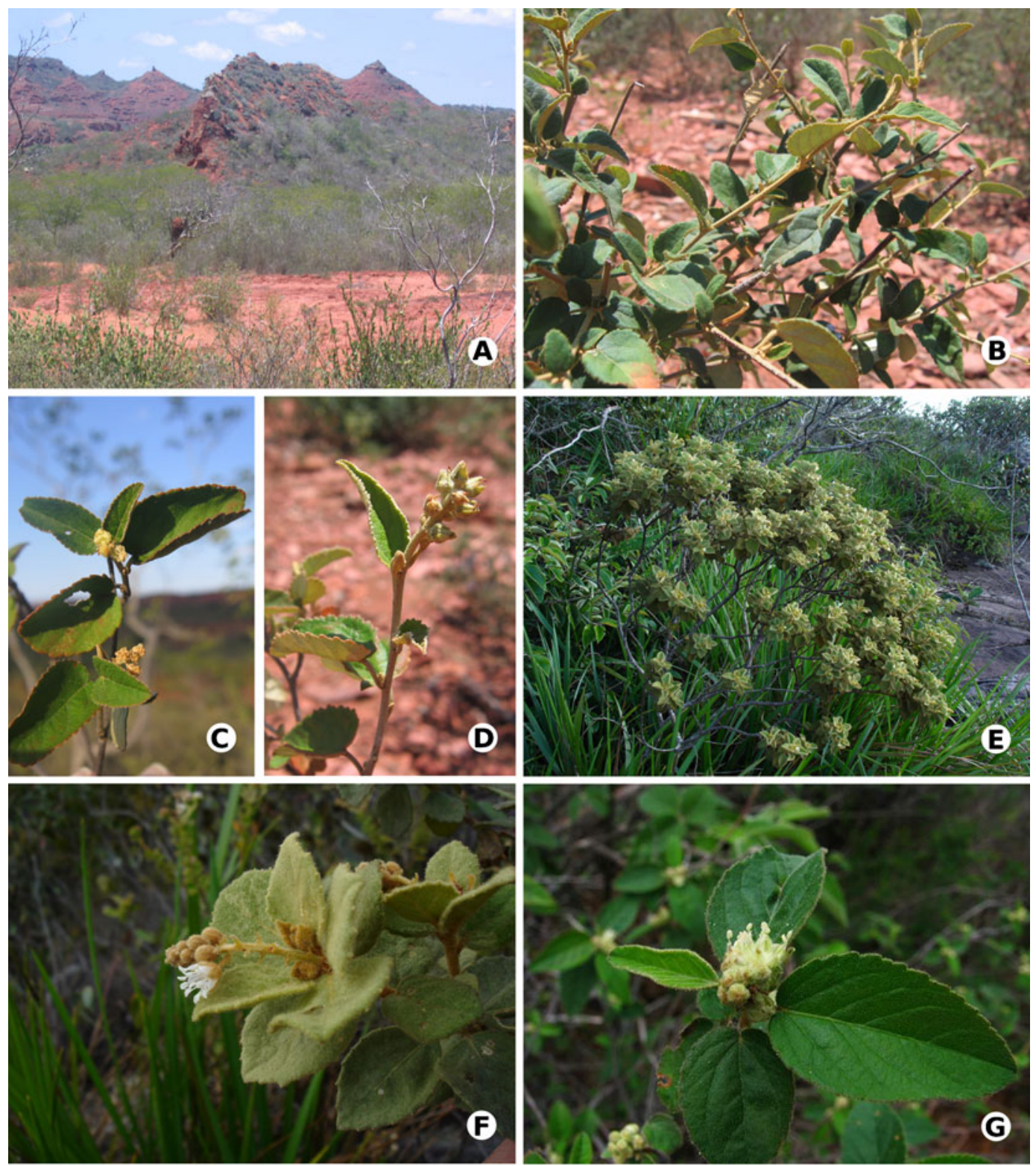

Fig. 1. A. Sandstone massif of the Município de Canudos, Bahia, the habitat of Croton arenosus. B-D. Croton arenosus. B. Habit. C. Staminate flower. D. Pistillate flower. E-F. Croton glandulosobracteatus. E. Habit. F. Staminate flower. G. Croton harleyi, staminate flower. Photographs by D.S. Carneiro-Torres (A-D), A. A Conceição (E-F), and J. C. Sobrinho (G).

lepidote, staminate flowers distal and continuous with the proximal pistillate flowers; bracts linear, margin entire, $0.5-1 \mathrm{~mm}$ long. Staminate flowers yellowish-green, $3-5 \mathrm{~mm}$ long, sparsely spaced along the rachis; pedicel 1.5-2.5 mm long; sepals 5, ovate to ovate-lanceolate, $1.5-2.5 \times 1-2 \mathrm{~mm}$, adaxial surface glabrous, abaxial surface scabrous; petals 5, lanceolate, $2-3 \times 1-1.5 \mathrm{~mm}$; stamens 11-12; receptacle pilose. Pistillate flowers silvery yellow, sparsely spaced along the base of the rachis; pedicel 1-1.5 mm long; sepals 5 , unequal, valvate, connate at the base, oblong to lanceolate, $3-4.5 \times 1-2.5 \mathrm{~mm}$, mar- 


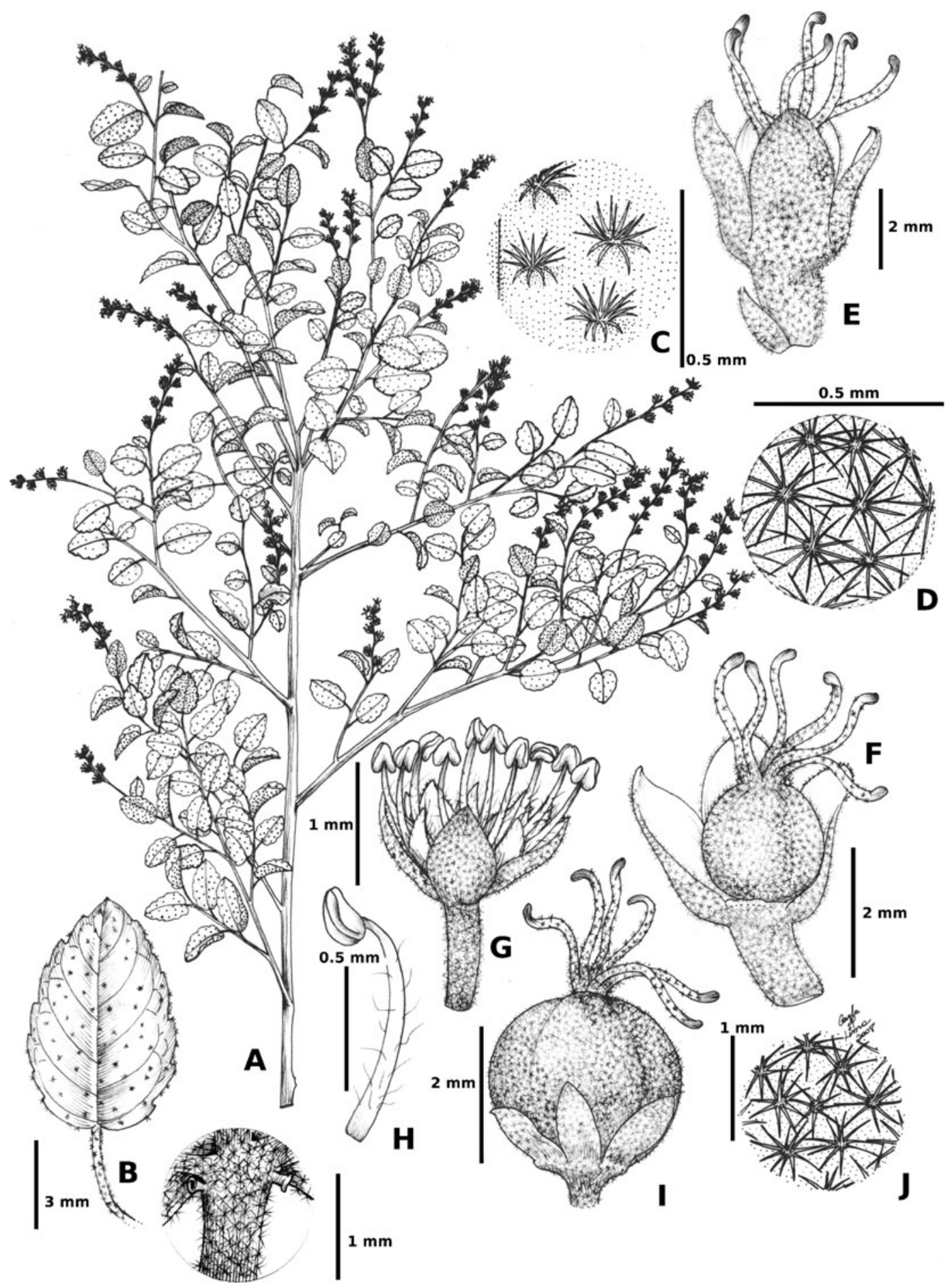

Fig. 2. Croton arenosus. A. Habit. B. Leaf. C. Leaf indumentum of the adaxial surface. D. Leaf indumentum of the abaxial surface. E. Pistillate flower. F. Pistillate flowers with two sepals removed. G. Staminate flower. H. Stamen. I. Fruit. J. Fruit indumentum. (From the holotype.) 
gin entire, adaxial surface pilose, abaxial surface stellate to stellate-lepidote; nectary disk 5-lobed, glabrous, petals absent, ovary globose, 2-3.5 mm diam., stellate-lepidote; styles 3, deeply bifid, pilose at the base and part way up the branches. Capsules 5-6 $\times 5-$ $6 \mathrm{~mm}$, ferruginous, incanous to tomentose; seeds ellipsoidal, 4-5×3-4 mm, smooth, carunculate.

Distribution and Ecology.-The species is restricted to the sandy Caatingas of Canudos, within the Biological Station of Canudos, in the northeastern corner of Bahia State, at altitudes of 400 to $450 \mathrm{~m}$ (Figs. 1A, 6).

Etymology.-The epithet refers to the sandstone outcrops of the Canudos area of Bahia where the species is endemic.

Phenology.-Flowering and fruiting from December to June.

Common name.-Caatinga-de-cheiro.

Conservation status.-The species is Critically Endangered CR (B2 ab (ii)) according to IUCN criteria (IUCN, 2001). It is only known from one locality with an area of occurrence estimated to be less than $100 \mathrm{~km}^{2}$.

Additional specimens examined. BRAZIL. Bahia: Município Canudos, Reserva Biológica Esquentada, 18 Feb 2004 (fl, fr), Miranda et al. 615 (HUEFS); 18 Jan 2006 (fl), Sossegolo et al. 198 (ALCB); 19 Sep 2006 (fl), Carneiro-Torres et al. 779 (HUEFS); 30 Jun 2007 (fl), Carneiro-Torres et al. 993 (HUEFS, SP); 23 Mar 2007, (fr), Dórea \& Oliveira 25 (HUEFS).

Croton arenosus is morphologically most similar to $C$. triangularis Müll. Arg., a species in Croton sect. Geiseleria (Klotzsch) Baill. that also occurs in Bahia, but in the southwestern part of the state (Caetité, Igaporã, Licínio de Almeida, and Monte Santo). rather than in the northeast where $C$. arenosus occurs. The two species are similar in their overall aspect, and they share several characters such as leaves with two glands at the base, scabrous abaxial leaf surfaces, entire stipules, inflorescences with linear bracts, staminate flowers with 10-12 stamens, and pistillate flowers with entire, eglandular sepals. Croton arenosus differs from $C$. triangularis in having elliptic to ovate leaves, eglandular leaf margins, unequal sepals in the pistillate flowers, stellate-lepidote ovaries, and bifid styles (vs. triangular-ovate leaves, leaf margins with stipitate glands, equal sepals in the pistillate flowers, tomentose ovaries, and multifid styles in C. triangularis).

Croton glandulosobracteatus Carn.-Torres \& Cordeiro, sp. nov. Type: Brazil. Bahia: Município de Mucugê, Serra do Gobira, Parque Nacional da Chapada Diamantina, $13^{\circ} 5^{\prime} \mathrm{S} 41^{\circ} 22^{\prime} \mathrm{W}, 16 \mathrm{Sep} 2006$ (fl, fr), $A$. $A$. Conceição, D. Cardoso \& E. R. Souza 1877 (holotype: HUEFS; isotypes: HUESB SP), (Figs. 1E-F, 3A-I, 5E-H, 6).

Croton luetzelburgii Pax \& K. Hoffm. affinis sed glandulis stipularum breviter stipitatis, petiolis eglandulosis, glandulis ad margines limbi sessilibus, staminibus 11-13, floribus femineis sessilibus vel subsessilibus differt.

Monoecious shrub or subshrub, erect, 0.5$1.5 \mathrm{~m}$ tall, foliage yellowish-green, trichomes stipitate, appressed stellate with a porrect central radius, latex clear. Leaves simple, alternate, appearing opposite at the branch tips, papyraceous to chartaceous, penninerved, blade elliptic to orbicular, $1.8-3 \times$ $1.6-3 \mathrm{~cm}$, apex acute to obtuse, base truncate to rounded, symmetric, margin sparsely glandular-denticulate, both surfaces tomentose to velutinous, yellowish-green to cinereous, glands absent at the base of the blades, petiole 3.5-7 $\mathrm{mm}$ long, tomentose; stipules fimbriate, glandular, lanceolate, $2-3 \mathrm{~mm}$ long, persistent. Inflorescences terminal, bisexual, 1.2-4 cm long, tomentose, stellate, staminate and pistillate flowers distributed continuously along the rachis; bracts linear, margin fimbriate-glandular, $2-3 \mathrm{~mm}$ long. Staminate flowers yellowish-white, 6.5$9 \mathrm{~mm}$ long, congested; pedicels $3-4 \mathrm{~mm}$ long; sepals 5, ovate-lanceolate, 2.3-4.3 $\times 2-$ $3 \mathrm{~mm}$, adaxial surface glabrous, abaxial surface stellate-pubescent; petals 5, spathulate to obdeltoid, 4-5×3-4 mm, stamens 11-13, receptacle pilose. Pistillate flowers yellowish, 6-8 mm long, congested, sessile to subsessile; sepals 5, free, equal, valvate, lanceolate, 4-4.5 $\times 2.5-3 \mathrm{~mm}$, margin glandular, both surfaces stellate, nectary disk 5-lobed, glabrous; petals absent, ovary globose, 3-4 mm diam., tomentose; styles 3, united at the base, 2-fid, pubescent on the connate portion, with appressed stellate trichomes with a porrect central radius. Capsules yellow-green, 


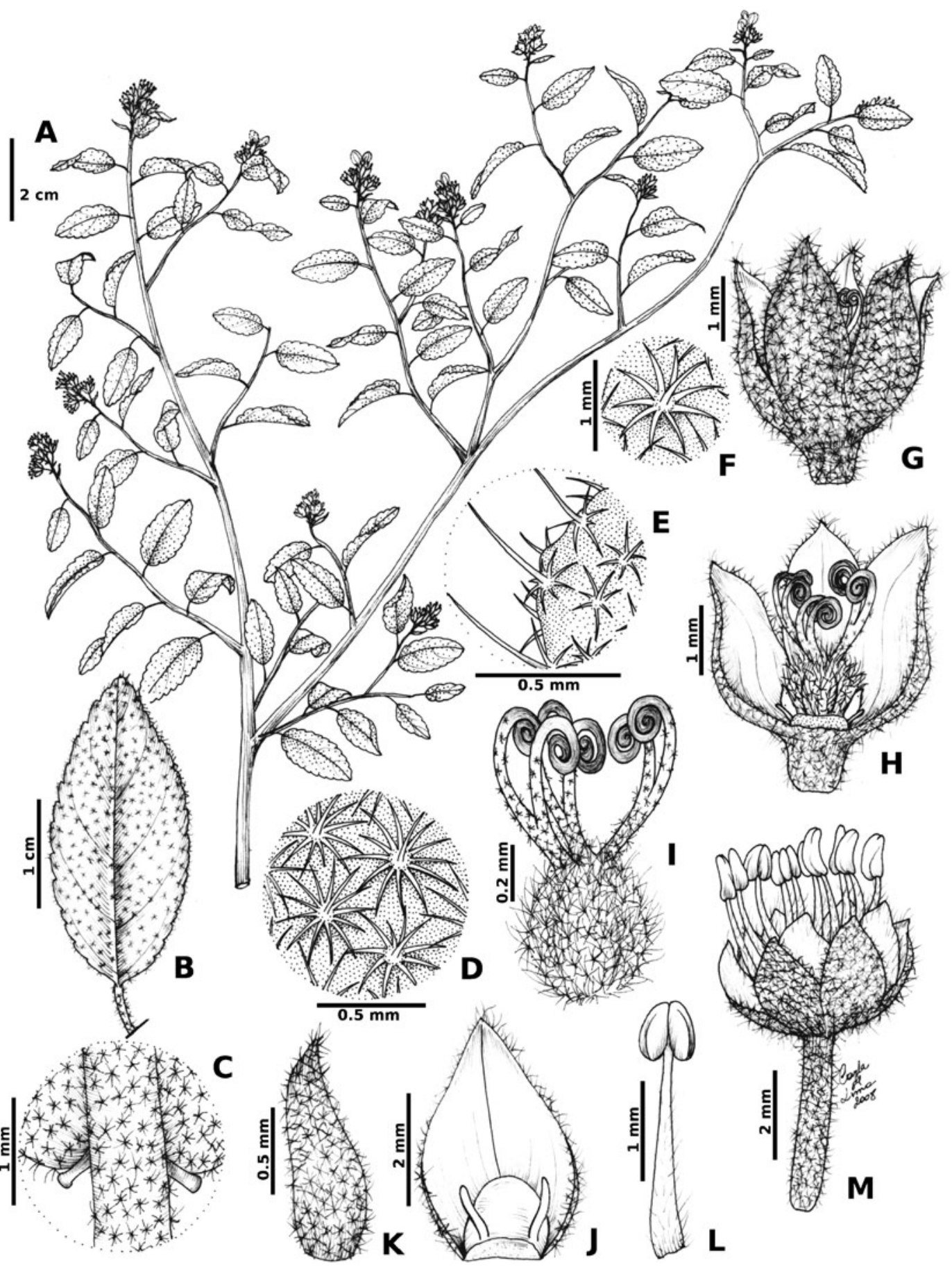

Fig. 3. Croton harleyi. A. Habit. B. Lamina. C. Leaf base with two glands. D. Leaf indumentum of the adaxial surface. F. Detail of leaf trichome. G. Pistillate flower. H. Pistillate flower with two sepals removed. I. Gynoecium. J. Adaxial surface of sepal and L. Stamen. M. Staminate flower. (From the holotype.) 
3-6 $\times 3-5.5 \mathrm{~mm}$, tomentose; seeds ellipsoid, 4-4.5 $\times 2-3 \mathrm{~mm}$, smooth, carunculate.

Distribution and Ecology.-This species is restricted to the campos rupestres of the Cadeia do Espinhaço from the Município de Santana do Riacho in central Minas Gerais state to the Município de Palmeiras in Bahia state, at elevations between 970 and $1850 \mathrm{~m}$ (Fig. 6).

Etymology.-The specific epithet refers to the species' glandular bracts.

Phenology.-Flowering and fruiting throughout the year.

Conservation status.-This species is not threatened according to the criteria of the IUCN (2001). It occurs in many localities and conservation areas.

Additional specimens examined. BRAZIL. Bahia: Município de Abaíra, Campo Cigano, 28 Jan 1992 (fl), Stannard et al. H50839 (CEPEC, HUEFS, K, SP, SPF); Serra do Bicota, 22 Apr 2003 (fl), Miranda et al. 554 (HUEFS, SP). Município Caetité, 15 Mar 1995 (fl, fr), Punt 2002 (MBM). Município Lençóis, middle and upper slopes of Pai Inácio ca. $15 \mathrm{~km} \mathrm{NW}$ of Lençóis, 24 May 1980 (fl), Harley 22485 (SPF, CEPEC); (fl) Harley 22551 (SPF, CEPEC); Morro da Mãe Inácia, 18 Aug 1996, fl., Grillo \& Conceição 32 (SPF). Município Mucugê, 4 Feb 1974 (fr), Harley 15958 (CEPEC, RB); road Mucugê-Andaíra, 3-5 km N from Mucugê, 9 Nov 1988 (fl, fr), Sano et al. CFCR14386 (SPF, K, SP, CEPEC); Pico do Gobira, 4 Aug 2004 (fl, fr), Borba et al. 1828 (HUEFS), 20 Jan 2005 (fl), Souza et al. 1035 (HUEFS), 18 Nov 2005 (fl), Carneiro-Torres et al. 601 (HUEFS). Município Palmeiras, 12 Jun 1981 (fl, fr), Mori et al. 14379 (CEPEC); 19 Feb 1994 (fl), Harley et al. CFCR14284 (SPF); Morro do Pai Inácio, 2 Feb 2000 (fl), Conceição 775 (SPF), 27 May 2002 (fl), Lima et al. 160 (SPF, MO). Município Piatã, road between the district Mato Grosso and the base of the Morro do Itabira, 26 Jun 2003 (fl), Sano et al. CFCR14680 (SPF); Morro Três Morros, 19 Jan 2006 (fl), Conceição et al. 1632 (HUEFS, SP); (fl, fr), Conceição et al. 1634 (HUEFS, SP). Município Rio de Contas, Pico das Almas, 19 Feb 1987 (fl), Harley et al. 24507 (K, SP, SPF). Município Rio do Pires, Garimpo das Almas, 24 Jul 1993 (fl), Ganev 1962 (HUEFS). Minas Gerais: Município Santana do Riacho, side road of Highway Belo Horizonte-Conceição do Mato Dentro (MG 010), trail access to the Cachoeira do Gavião, 22 Jun 2000 (fl, fr), Fiaschi \& Costa 347 (SPF).

Based on morphological characters such as the nonviscous, stellate indumentum; eglandular leaf bases; glandular bracts, stipules, and pistillate sepals; short terminal inflorescences; and sessile to subsessile pistillate flowers, Croton glandulosobracteatus fits well in Croton sect. Barhamia (Klotzsch) Baill., following the circumscription of Webster (1993). This new species appears to be morphologically most similar to Croton luetzelburgii Pax \& K. Hoffm., from which it differs in having stipules with short stipitate glands on the margins, eglandular petioles, leaf margins with sessile glands, 11-13 stamens, and sessile or subsessile pistillate flowers (vs. stipules with long stipitate glands, petiole with sparse stipitate glands, leaf margins with stipitate glands, 1225 stamens, and pistillate flowers with pedicels 4-5 mm long in C. luetzelburgii).

In an earlier revision of Croton of the Cadeia do Espinhaço in the State of Minas Gerais (Lima \& Pirani, 2003), Croton glandulosobracteatus was treated as Croton aff. desertorum Müll. Arg.

Croton harleyi Carn.-Torres \& Cordeiro, sp. nov. Type: Brazil. Bahia: Município de Rio de Contas, Serra do Rio de Contas, 1349'16" $\mathrm{S} 41^{\circ} 35^{\prime} 50^{\prime \prime} \mathrm{W}, 5 \mathrm{Dec} 2004$ (fl), R.M. Harley, A.M. Giulietti, E.A. Correia \& M.S. Ribeiro 55288 (holotype: HUEFS; isotypes: SP, HUESB). (Figs. 1G, 4A-M, 5I-J, 6)

Crotoni eremophilo Müll. Arg. affinis, sed foliis ad margines eglandulosis, pari glandium ad baseum subtus praeditis, stipulis glandulis destitutis, sepalis femineis inaequalibus, eglandulosis, stylis bifidis differt.

Monoecious erect shrub, 1-2 m tall, branches greenish-ferruginous, trichomes appressed stellate and fasciculate, latex translucent. Leaves alternate, simple, membranaceous, penninerved, blade elliptic, $2-4.8 \times 0.9-$ $2 \mathrm{~cm}$, apex acute, base cuneate, symmetric, margin serrulate, marginal glands absent, adaxial surface greenish-ferruginous, scabrous, abaxial surface strigose, with two types of trichomes (globose, glandular, and sessile; or stipitate and appressed stellate), glands at the base of leaf blades 2 , shortly stipitate, rounded; petiole 4-8 $\mathrm{mm}$ long, pubescent; stipules entire, linear, 2-3 mm long, deciduous. Inflorescences terminal, bisexual, 1-2 cm long, stellate, staminate flowers distal and continuous with proximal pistillate flowers; bracts linear, margin entire, 3-4 mm long. Staminate flowers yellowgreen, 5-6 mm long, congested, one or two staminate flowers per node; pedicel 3-4 mm long; sepals 5, ovate to ovate-lanceolate, $2-3 \times$ $1.5-2.5 \mathrm{~mm}$, adaxial surface glabrous, abaxial 


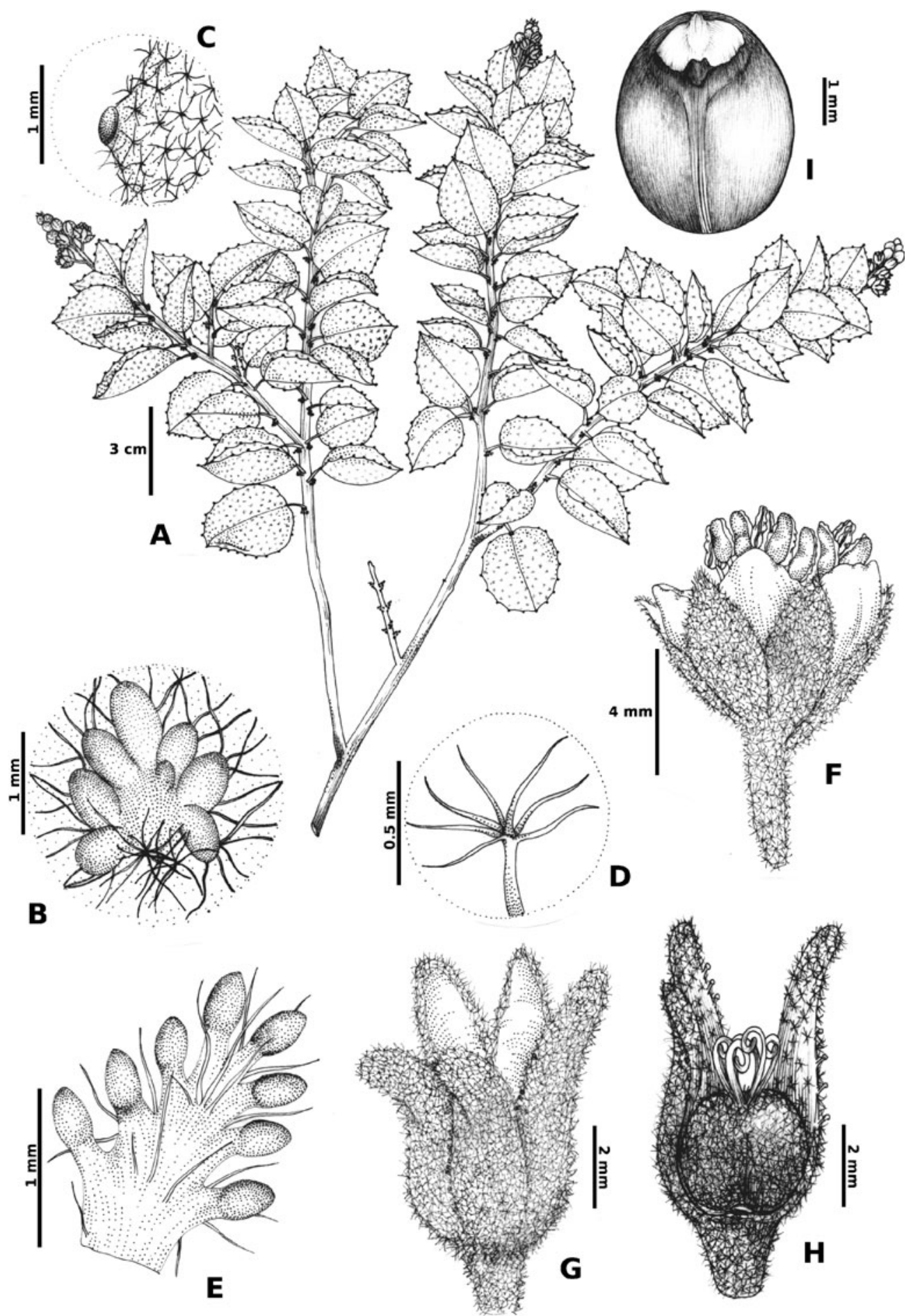

Fig. 4. Croton glandulosobracteatus. A. Habit. B. Stipule. C. Marginal leaf gland. D. Stipitate stellate trichome. E. Bract. F. Staminate flower. G. Pistillate flower. H. Pistillate flower with two sepals removed. I. Seed. (From the holotype.) 

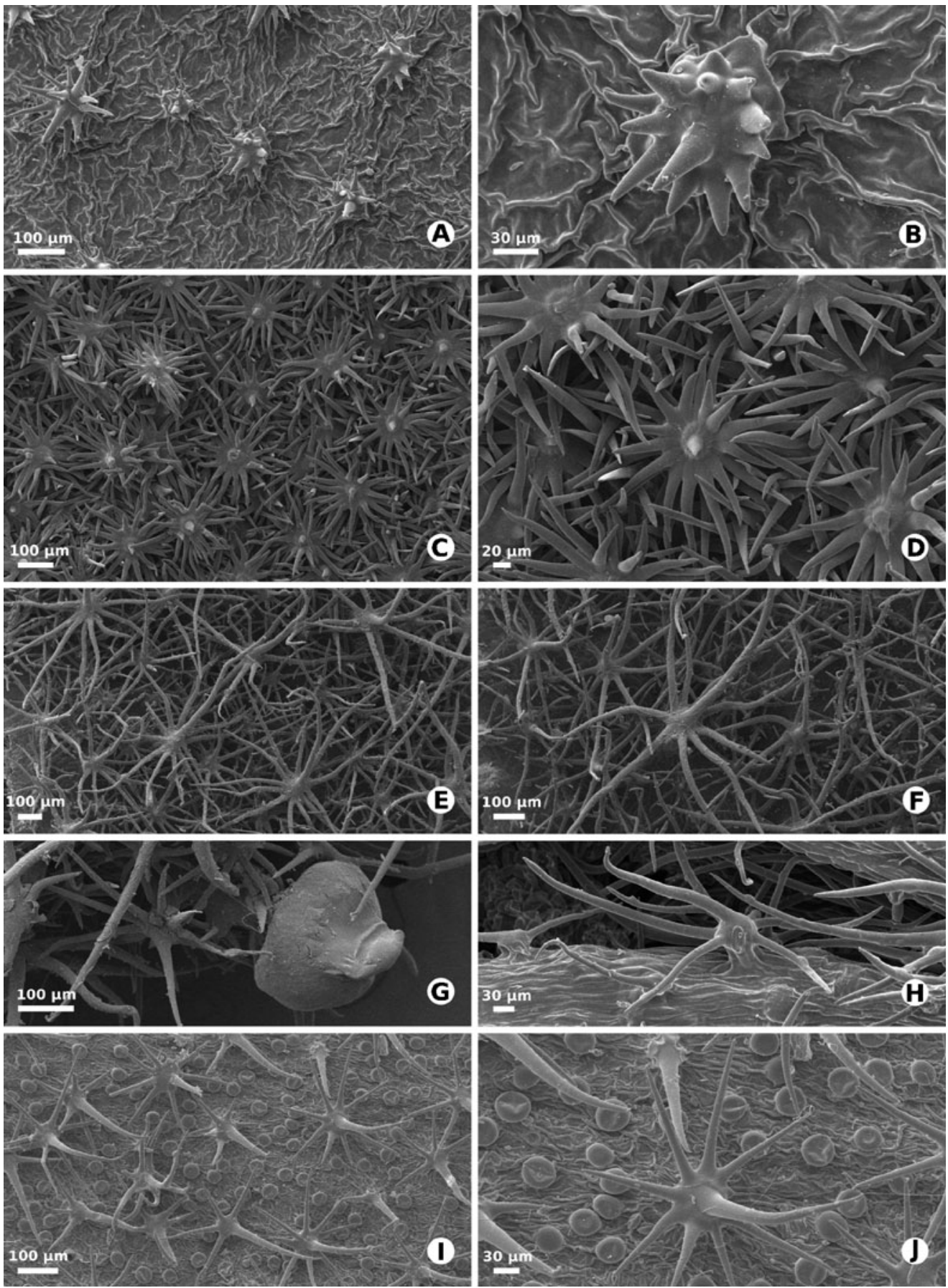

Fig. 5. Scanning electron micrographs of leaf trichomes. A-D. Croton arenosus (from the holotype). A. Leaf indumentum of the adaxial surface. B. Fasciculate trichome on the adaxial leaf surface. C. Leaf indumentum of the abaxial surface. D. Stellate-lepidote trichome of the abaxial leaf surface. E-H. Croton glandulosobracteatus (Souza 1035, HUEFS). E. Leaf indumentum of the adaxial surface. F. Porrect, stipitate, appressed stellate trichome of the adaxial leaf surface. G. Marginal leaf gland. H. Porrect, stipitate, appressed stellate trichome on the style. I-J. Croton harleyi (Fernandes 106352, HUEFS). I. Leaf abaxial surface. J. Larger stipitate, appressed-stellate trichomes with porrect central radius, together with much smaller, globose, sessile, glandular trichomes on the abaxial leaf surface. 


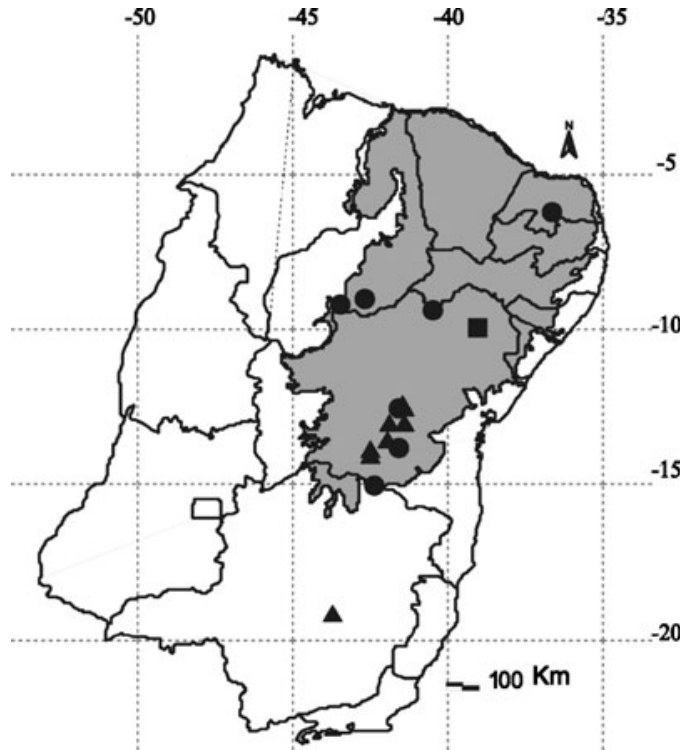

Fig. 6. Map of northeastern Brazil with Caatinga indicated by shading. Geographic distributions of $C$. arenosus (square), C. glandulosobracteatus (triangles), and C. harleyi (circles).

surface stellate; petals 5 , elliptic, 3-4×1.8$2.5 \mathrm{~mm}$; stamens 11; receptacle pilose. Pistillate flowers green-ferruginous, 6-7 mm long, congested, sessile; sepals 5, free, unequal, valvate, ovate to narrowly elliptic, $3.5-6 \times 2.5-3 \mathrm{~mm}$, margin entire, tips becoming somewhat revolute, adaxial surface glabrous, abaxial surface stellate, nectary disk 5-lobed, glabrous; petals reduced to glandular filaments; ovary globose, 2-3×2-3 mm, stellate; styles 3 , united at the base, bifid, pubescent on the lower portion. Capsules green-ferruginous, 5-6 $\times 5-6 \mathrm{~mm}$, stellate; seeds ellipsoid, 4-5×3-4 mm, smooth, carunculate.

Distribution and habitat.-This species is endemic to the Caatinga of the states of Piauí, Rio Grande do Norte, Pernambuco, and Bahia, where it grows on sandy soils of sandstone outcrops at elevations of 640 to 930 m (Fig. 6).

Etymology.-The epithet honors Raymond Mervin Harley, an extraordinary botanist who, with his numerous collections from the Chapada Diamantina, has contributed greatly to our knowledge of Croton and other Euphorbiaceae.

Phenology.-Flowering and fruiting from December to April.
Conservation status.-This species is not threatened according to the criteria of the IUCN (IUCN, 2001). It occurs in numerous localities and conservation areas.

Additional specimens examined. BRAZIL. Bahia: Município Mortugaba, 16 Mar 1994 (fr), Souza et al. 5527 (ESA). Município Palmeiras, trail to Serra Preta, 28 Feb 2003 (fr), Melo et al. 3602 (HUEFS). Município Rio de Contas, Serra do Rio de Contas, 16 Jan 1974 (fl, fr), Harley et al. 15125 (RB, CEPEC); 5 Dec 2004 (fl), Harley et al. 55289 (HUEFS). Pernambuco: Município Petrolina, 1976 (fi), Angélica IPA46904 (IPA). Piauí: Município Caracol, Serra das Confusões, 8 Dec 1980 (fl), Fernandes \& Del' Arco s/ $n^{\circ}$ (HUEFS106352, EAC9099), 22 Jun 2007 (fl), Carneiro-Torres et al. 923 (HUEFS). Município São Raimundo Nonato, Serra da Capivara, 31 Jan 1984 (fr), Emperaire 2263 (RB), 31 Jan 1984 (fl), Emperaire 2292 (RB). Rio Grande do Norte: Município São Vicente, 1 Mar 1980 (fl), Oliveira et al. 135 (MOSS).

Based on morphological characters such as unequal sepals in the pistillate flowers, stipitate glands at the base of the leaves, dentate leaf margins, and bifid styles, this species should belong to Croton section Geiseleria. In habit and general leaf size, shape, and pubescence, Croton harleyi is morphologically similar to $C$. eremophilus Muell. Arg., but differs from it in having a pair of glands at the base of leaves, eglandular leaf margins and stipules, unequal and eglandular pistillate sepals, and bifid styles (vs. glandular leaf margins, eglandular leaf bases, stipules with marginal glands, pistillate sepals equal and with marginal glands, and styles tetrafid in C. eremophilus).

\section{Acknowledgments}

The following institutions provided financial support to the senior author: Universidade Estadual do Sudoeste da Bahia, Universidade Estadual de Feira de Santana, Programa de Biodiversidade (MCT), and the Fundação de Amparo à Pesquisa do Estado da Bahia (FAPESB). We are grateful to the curators of all the herbaria consulted for providing access to their collections. Thanks to Tarciso Filgueiras from the herbarium IBGE for the revision of Latin diagnoses and also to Carla Lima for the botanical illustrations. We kindly thank the reviewers Benjamin van Ee and Hans-Joachim Esser for their very helpful comments to improve an earlier version of the manuscript. 


\section{Literature Cited}

Andrade Lima, D. 1982. Present day forest refuges in northeastern Brazil. Pp. 245-251 in G. T. Prance (ed.), Biological diversification in the Tropics. Columbia University Press, New York.

Berry, P. E., A. L. Hipp, K. J. Wurdack, B. van Ee \& R. Riina. 2005. Molecular phylogenetics of the giant genus Croton and tribe Crotoneae (Euphorbiaceae sensu stricto) using ITS and trnL-trnF DNA sequence data. Amercan Journal of Botany 92: 1520-1534.

Carneiro-Torres, D. S. 2009. Diversidade de Croton L. (Euphorbiaceae) no Bioma Caatinga. Tese de Doutorado do Programa de Pós-Graduação em Botânica da Universidade Estadual de Feira de Santana, Bahia. 296pp.

Caruzo, M. B. R., R. Riina, I. Cordeiro \& P. E. Berry. 2008. Croton campanulatus (Euphorbiaceae s.s.), a new species from the Brazilian Atlantic rain forest. Brittonia 60: 261-264.

ESRI. 1999. Environmental Systems Research Institute. Advance Arcview GIS

Giulietti, A. M., R. M. Harley, L. P. de Queiroz, M. R. V. Barbosa, A. L. Bocage Neta \& M. A. Figueiredo. 2002. Espécies endêmicas da caatinga. Pp. 103-115 in E. V. S. B. Sampaio, A. M. Giulietti, J. Virgínio, J. \& C. F. L. Gamarra-Rojas (eds.), Vegetação e Flora da Caatinga. Recife, Pernambuco, Brazil.

Govaerts, R., D. G. Frodin \& A. Radcliffe-Smith. 2000. A World Checklist and Bibliography of Euphorbiaceae (and Pandaceae). Royal Botanic Gardens, Kew, vol. 2: 415.

IUCN. 2001. IUCN Red List categories and criteria: Version 3.1. IUCN Species, Survival Commission. IUCN, Gland, Switzerland and Cambridge, U.K.

Lima, L. R. \& J. R. Pirani. 2003. O gênero Croton L. (Euphorbiaceae) na Cadeia do Espinhaço, Minas Gerais, Brasil. Bol. Bot. Univ. São Paulo 21(2):299-344.

Pennington, R. T., D. E. Prado \& C. A. Pendry. 2000. Neotropical seasonally dry forests and Quaternary vegetation changes. J. Biogeography 27. 261.

, G.P. Lewis \& J.A. Ratter. 2006. An overview of the plant diversity, biogeography and conservation of Neotropical savannas and seasonally dry forests. Pp. 1-29 in R. T. Pennington, G. P. Lewis \& J. A. Ratter (eds.), Neotropical savannas and seasonally dry forests: Plant diversity, biogeography and conservation. CRC Taylor \& Francis Group, London.

Prado, D. E. 2000. Seasonally dry forest of Tropical South American: from forgotten ecosystems to a new phytogeographical unity. Edinburgh J. Bot. 57. 437461.

2003. As caatingas da América do Sul. Pp. 3-73 in I. R. Leal, M. Tabarelli \& J. M. C. Silva (eds.), Ecologia e conservação da caatinga. Universidade Federal de Pernambuco, Recife.

Queiroz, L. P. de. 2006. The Brazilian Caatinga: phytogeographical patterns inferred from distribution data of the Leguminosae. Pp. 121-157 in R. T. Pennington, G. P. Lewis \& J. A. Ratter (eds.), Neotropical savannas and seasonally dry forests: plant diversity, biogeography and conservation. CRC Taylor \& Francis Group, London.

. 2009. Leguminosas da Caatinga. Universidade Estadual de Feira de Santana, Feira de Santana 467pp.

A. Conceição \& A. M. Giulietti. 2006. Nordeste semi-árido: caracterização geral e lista das fanerógamas. Pp.15-364 in A. M. Giulietti \& L.P. de Queiroz (eds.), Instituto do Milênio do Semi-Árido, Diversidade e Caracterização das Fanerógamas do Semi-árido Brasileiro. Vol. I. Associação Plantas do Nordeste, Recife.

Rizzini, C. T. 1979. Tratado de fitogeografia do Brasil, aspectos sociológicos e florísticos, vol. 2. Edgard Blucher Ltda./EDUSP, São Paulo.

Sampaio, E. V. S. B. 1995. Overview of the Brazilian Caatinga, Pp. 35-63 in S. H. Bullock, H. A. Mooney \& E. Medina (eds), Seasonally Dry Tropical Forest. Cambridge University Press New York.

Velloso, A. L., E. V. S. B. Sampaio \& F. G. C. Pareyn. 2002. Ecorregiões: Propostas para o Bioma Caatinga. Associação Plantas do Nordeste-Nature Conservancy do Brasil, Recife.

Webster, G. L. 1993. A provisional synopsis of the sections of the genus Croton (Euphorbiaceae). Taxon 42: 793-823.

, M. J. Del-Arco-Aguilar \& B. A. Smith. 1996. Systematic distribution of foliar trichome types in Croton (Euphorbiaceae). Botanical Journal of the Linnaean Society 121: 41-57. 